\title{
COMPETITIVENESS IN ODL FROM STAKEHOLDERS' PERSPECTIVE: A REVIEW AND RESEARCH AGENDA
}

\author{
Nikhil KANT \\ ORCID: 0000-0002-0157-2866 \\ Research Scholar, SOMS, IGNOU \\ New Delhi, India
}

Received: 18/07/2018 Accepted: 05/09/2018

\begin{abstract}
Open and Distance Learning (ODL) in higher education has gained momentum in previous decades. ODL institutions too require competitiveness in the market place of educational products/ services through their capabilities and core competencies by adopting cost and/or differentiation strategy, especially due to the increasing competition arising from the existence of large number of institutions with similar objectives. The competition has further increased due to Liberalization, Privatization and Globalization, virtually collapsing the boundaries to access education being offered from any other country; technological developments; changes in demographics, societal \& economic structures; and most importantly emergence of online institutions with different nomenclatures. ODL institutions in India are in dire need of making strategic efforts to create and maintain sustainability in competitiveness by reaching out to larger sections of different stakeholders to satisfy their needs/ expectations in view of the huge untapped potential in India and abroad. All stakeholders are not equally important and influential and their identification is a critical step in selecting appropriate strategy for achieving competitiveness. This study sets the research agenda on the topic of competitiveness in ODL in higher education from the perspective of the relevant stakeholders and not learners only, with the help of Systematic Literature Review (SLR), showcasing the findings to provide the future research framework with a deeper understanding of ODL, Competitiveness, stakeholders and their interrelations in the Indian context.
\end{abstract}

Keywords: Competitiveness, open distance learning, stakeholders, stakeholders' perspective.

\section{INTRODUCTION}

Learning through Open and Distance mode has gained momentum in last few decades in the higher education sector in India along with its tremendous growth and expansion at global level. Institutions imparting education through Open and Distance Learning (ODL) mode have been incessantly trying to gain competitiveness through development of their capabilities, especially with the increasing competition due to increase in the number of institutions with similar objectives. ODL institutions in India are in dire need of making strategic efforts to create and maintain sustainability in competitive advantage by harnessing the resources available in the market of ODL through their core competencies using them in various locations, impactful usage of ICT, suitable marketing strategy, creditable reputation, differentiated study materials, creativity, innovations, relevant research etc. reaching out to larger sections of stakeholders to satisfy their needs and expectations efficiently, instead of paying attention to the expectations and needs of learners only. In recent times, there have been growing concerns regarding quality and credibility of the ODL system with the negative perceptions created amongst the stakeholders by information received through negative media articles, court decisions, employers' reluctance and easier entry of non serious players, which require these institutions to make extra efforts to live up to the ever increasing expectations of the various stakeholders, keeping in view the huge untapped potential in India and international level in the field.

There has been constant growth on the number of ODL institutions in higher education in India and at international level, while higher education institutions in conventional mode have also been thriving through 
course-offerings in ODL mode. The competition has ever increased due to Liberalization, Privatization and Globalization of education virtually collapsing the borders to access education being offered from any other country; relevant technological developments; new wave of economies; changes in demographics, society and family structures; and most importantly emergence of online institutions. Collectively, these transformations pose an unavoidable threat to the very existence and sustainability of the ODL institutions in India. The situation calls for a sincere attention towards study of stakeholders of ODL in India with focus on their strengths, weaknesses, opportunities and threats to respond to these changes more proactively in order to consolidate the institutions' position tapping the potentials in the markets of educational products and services. While at the ground level, the ODL system is facing stiff challenges with its quality, flexibility and sustainability to its learners, it needs to make sincere efforts to meet the expectations of various stakeholders as a promising alternative to the conventional system of education.

The previous studies have failed to contextualize and conceptualize the issue of competitiveness in ODL in higher education from the perspective of its various stakeholders in Indian circumstances. This study aims to set the research agenda for future research on the topic of competitiveness in ODL in higher education from the perspective of the relevant stakeholders and not learners only, with the help of Systematic Literature Review (SLR) and its steps of planning, conducting and reporting. The study also tends to showcase the findings in such a manner that it provides the framework or background for the future research with a deeper understanding of ODL, Competitiveness, stakeholders and their interrelations in the Indian context.

\section{METHODS AND MATERIALS}

The research method of Systematic Literature review (SLR) was found to be suitable for undertaking this study in its research design, which showcases a systematic plan or procedure based on selected assumptions to find the answer to the research questions (Creswell, 2009), which are : (a) Is there a need to identify indicators of competitiveness in ODL in Indian higher education in order to create and sustain competitive advantage for its survival?, (b) Is there a requirement to examine and evaluate the perceptions of all other important and influential stakeholders than learners only?, (c) Is there an urgency to test the validity of the distinction among the different key stakeholders of ODL in Indian higher education amongst primary and secondary stakeholders?

SLR employs the strategies of planning, conducting and reporting the review, as a form of Secondary Study, to summarize by identifying gaps in existing literature to set the research agenda for further research, through purposeful employment of identifying, evaluating and interpreting the previous studies and their findings in the relevant research areas, topics or interests. It requires more rigorous efforts than conventional reviews (Kitchenham, 2004). The process begun with the methods of screening, gathering and collating existing significantly relevant literature, to answer the research questions through primary studies, by weeding out non-relevant articles/papers for further consideration and analyzing/evaluating shortlisted literature through critical analysis only to select, connect, compare, and explain important information with respect to theories, opinions, outcomes and suggestions for future research, in the form of reporting of the review to present the findings of the review in such a manner that it proposes the research agenda to provide the framework or background for the future research with a deeper understanding of ODL, Competitiveness, stakeholders and their interrelations in the Indian context, being presented in the following sections.

The SLR explored research literature with the approach of undertaking comprehensive searches of relevant electronic Journals, databases and search engines such as ScienceDirect, Scopus, SpringerLink, Web of Science, CiteSeer, EBSCO, JSTOR, Elsevier, Google Scholar etc. accessible through the authors' university e-resource platform to ensure that maximum of the relevant literature on ODL, competitiveness and stakeholders were identified. The focus was maintained on the literature with highest relevance to the research questions.

The inclusion criteria for the search was employed as the studies in English and published in peer-reviewed journal only. The search string was constructed after deriving the major terms, checking the keywords from the studies already analyzed, identifying the synonymous terms and using Booleans OR and AND for joining major terms such as ODL, Open Distance Learning, Open Distance Education, Competitiveness, Competitive advantage, Stakeholder. The search strings were employed without any restriction of period 
of publication. Consequently, 214 studies (Research Papers/Articles=162, Thesis=3, Conference/Workshop Papers=17, Reports/Books=32) were identified excluding the studies which were stored/ published in more than one database/source. Number of articles thus retrieved were recorded after excluding them. But, they included studies not addressing adequately the research questions also, which needed to be excluded. Subsequently in the next stage, the articles without any focus on the interrelations amongst above components in their abstracts, main body, results and discussions were excluded for further consideration. The remaining relevant literature were found to be helpful in including additional articles in the final list with the help of their references/bibliographies, also. Finally, a list of 77 studies (Research Papers/Articles=57, Thesis=1, Conference/Workshop Papers=2, Reports/Books=17) was filtered after the application of the above inclusion/ exclusion criteria. The studies were assessed on the basis of their quality with respect to publications, aims, discussions, contextual information, findings and their presentation, citations by others etc., followed by data extraction and data synthesis in order to summarize through reporting of the relevant results from the analysis of the identified studies. This phase was completed with the strategy of finding answers to the research questions through consultation of the extracted data, looking out for additional findings beyond the research questions and identifying the gaps in the extant literature to develop research agenda in the form of recommendations for the future research.

\section{MEANINGS \& DEFINITIONS}

\section{Open \& Distance Learning (ODL)}

The concept of Open and Distance Learning (ODL) emanates from the combination of 'Open Learning' which is a philosophy and 'Distance Learning' which is a mode of delivery, complementing each other. While 'Distance Learning' encompasses all the teaching-learning arrangements between learners and teachers existing in a space and time separated set-up; 'Open learning' an array of innovations and reforms advocating flexibility to the learner in terms of entry, exit, pace, place, methods, choice, course combinations, assessment and completion of the course. The ODL system attempts to eradicate inequality by offering opportunities to larger sections of the society (UGC, n.d.-b). More inclusively and expressively, UNESCO (2002) defines ODL as an educational process, where all or most of the teaching and communication take place with the help of artificial medium such as print or electronic medium, as the teachers and learners are removed from each other in space and/or time. As an effective educational method, ODL has been found to be most potent tool to battle the educational problems in developing countries, which has emerged as a new teaching model which helps people teach and learn anytime and anywhere, using multimedia and technology advancement (Faridi \& Ouseph, 2014). ODL follows an institution based formal educational process resulting from the association of educational technology and communication connecting learners, teachers and other resources, where these groups are separated from one other. With the growing needs of education and training in developing countries, ODL is seen as an important tool to reach young and adult prospective learners to meet their needs, which largely remain unmet because of constraints related to financial, geographical and other reasons (UNESCO, 1997), and is an effective instrument of supporting and supplementing conventional mode of education. ODL, with constructive support of ICT, has tremendous potential to address the problem of access and make available a new alternative form of capacity building as a viable option (McQuaide, 2009), which has become, over the time, an indispensable part of the global educational system, both in developing countries as well as developed countries, aiming to address the problems related to quality, equity and access, in view of the technological advancement and growing needs of skill up gradation through training and retraining (UNESCO, 2002).

\section{Competitiveness}

Studies and research related to competitive advantage have been at the centre of the discipline of strategic management, especially after the publication of Porter's landmark model of "Five Forces of Competitive Position" which conceptualized a widely accepted perspective for the assessment/ analysis of the competitive position and strength of an organization. It gave birth to the five forces of competitive position that are Threat of new market entrants, Threat of substitute products, Buyers' bargaining power, Suppliers' bargaining power, and Rivalry 
amongst the present competitors (Porter, 1980). He argues that competitive advantage comes out of discovery and implementation of unique and distinctive ways of competing that can be sustained over the time, further recommending three generic strategies of competitive advantage viz. Cost leadership, Differentiation and Focus. Cost leadership is achieved through the products/services at the lowest cost supported with high volumes and uncompromised quality; Differentiation through becoming market leader with the help of products/services different from rivals; and Focus through gaining leadership position in a niche market segment either through the cost leadership or through differentiation strategy. Further, The Resource-based View attempts to identify the organizational internal factors that may help it gain competitive advantage, suggesting that business methods, means, skills, and resources' capabilities enable an organization to outperform its present and future competitors, leading to competitive advantage (Barney, 2001), which an organization harnesses for developing and implementing strategies through its own rare, valuable, non-imitable, and organized resources, supporting to improve its overall effectiveness and efficiency (Barney, 1991). Teece, Pisano, \& Shuen (1997) argue that the ability of the organization to combine its resources effectively may help it achieve competitive advantage. While Grant (1991) emphasizes that maintaining sustainability of competitive advantage is dependant on idiosyncratic, not easily transferable or replicable resources; Prahalad \& Hamel (1990) argue that the basic capabilities inherent in an organization's competitive advantage which can be deployed across several product markets, referred to as core competencies, create sustainability of competitive advantage. Competitive advantage is assumed to be the result of suitable strategy execution, speed, agility, and resource implementation better than competitors (Barney, 1991; Bharadwaj, 2000). Kaur (2017) has attempted to showcase the ten common outcomes of competitiveness on the basis of her interpretations in extant literature, which are displayed in Figure 1.

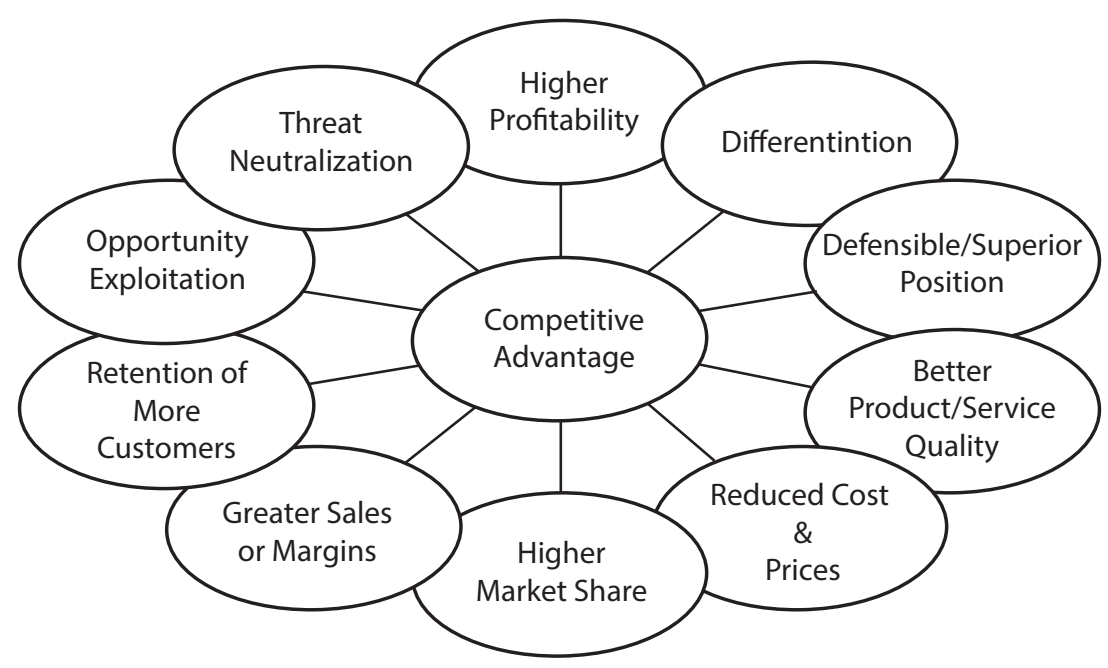

Figure 1. Ten common outcomes of Competitive advantage (Kaur, 2017)

Competitiveness is the organizational ability to compete in the markets with a strategy for favorable consequences to create and maintain a competitive advantage for gaining better performance than their competitors (Porter, 1985, 1998). But, competitiveness measurement is a complex activity (Crouch \& Ritchie, 1999). There have been efforts to measure it in previous studies either with the help of financial measures (Barrett, Davidson, Prabhu, \& Vargo, 2015; Krell \& Matook, 2009; Prescott, 2014; Sigalas, Economou, \& Georgopoulos, 2013) or non financial measure such as creative process of product/service development, Product/service quality, customer responsiveness reflected through customer retention/attraction, cost savingleffectiveness, market differentiation, strategic planning, core competence, and social responsibility (Agha, Alrubaiee, \& Jamhour, 2012; Al-alak \& Tarabieh, 2011; Barrett et al., 2015; Diab, 2014; Epetimehin, 2011; Heywood \& Kenley, 2008; Kuettner \& Schubert, 2012; Majeed, 2011; Matikiti, Afolabi, \& Smith, 2012; Prescott, 2014; Schatz \& Bashroush, 2016; Sigalas et al., 2013; Vahid et al., 2013; Kasasbeh, Harada, \& Noor, 2017), which need to be identified in the specific context for better understanding to the researchers and practitioners, in future. 


\section{Stakeholders}

Researchers and Practitioners have continuously been focusing on the expansion and elaboration of the significance of Stakeholders after the seminal book "Strategic Management: a stakeholder approach" by Freeman (1984) came into existence, which defines stakeholder as a group/individual which gets affected by/can affect the achievements of objectives and policies of the organization (Freeman, 1984). Stakeholders' pressure has ever increased in the form of demand of meeting their respective expectations to force organizations to integrate them with their decision making process and strategies (Hart, 1995; Kassinis \& Vafeas, 2006). Pursuant to a strategic approach, Stakeholder analysis has been used, in recent times, for designing, implementing and evaluating a proposal, undertaken through -List preparation of stakeholders, Selection of their relevant interests, evaluation of their importance/ influence/ implications/ cooperation amongst selected stakeholders and determining when, how and which of them to participate (ODA, 1995). Stakeholders are categorized as primary and secondary stakeholders based on their relationships with the organizations, the primary stakeholders engaging in formal transactions with the organizations, and the secondary stakeholders not engaging in formal transactions with them (Clarkson, 1995). Further, Mitchell \& Wood (1997) classify stakeholders on the basis of the three attributes viz. power, legitimacy, and urgency, which force organizations to take different measures for different stakeholders. The 'Stakeholder Theory' (Freeman, 1984) argues that an organization has multiple stakeholders such as customers, communities, workers, shareholders, suppliers, mangers, unions etc., who can influence the organizational performance. Organizations need to satisfy all the stakeholders through appropriate strategies, instead of making efforts to satisfy the expectations of any particular stakeholder only. Stakeholders may seek different levels/types of strategy on account of the difference in their interests (Rueda-Manzanares, Aragón-Correa, \& Sharma, 2008), making awareness of the relevance of the stakeholders, significant for organizations (Freeman, 1984). In such situations, identification of relevant stakeholders which may influence and are important for the achievements of organizational policies and objectives have drawn enough attention of Researchers and Practitioners, in recent times (Figure 2).

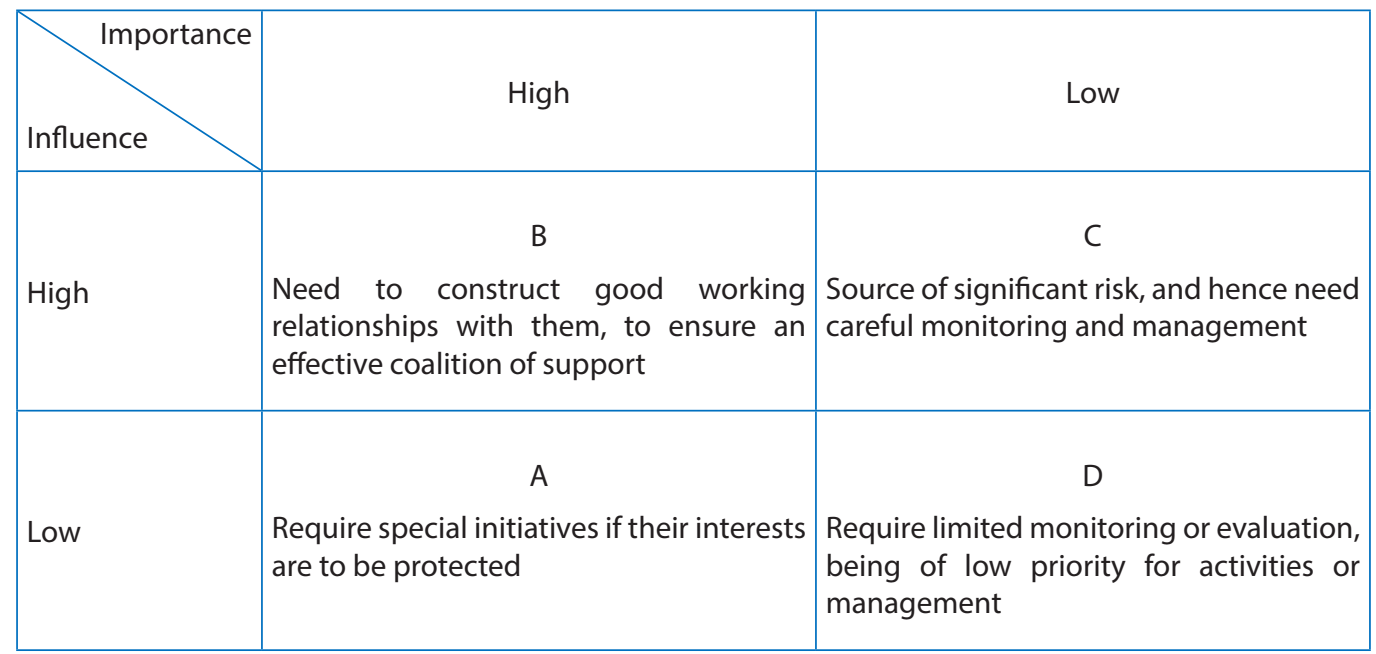

Figure 2. Stakeholders' Identification Matrix (Adapted from ODA, 1995)

Salience of the stakeholders in the organizational perceptions, is found to be positively related to the cumulative effect of the stakeholders' internal attributes i.e. power (will imposing ability), legitimacy (socially accepted right-wrong conducts) and urgency (immediacy in terms of attention to be paid), compelling organizations to decide priorities to their respective demands (Mitchell \& Wood, 1997). There have been several attempts by previous studies to classify stakeholders based on their mutual dependence on the organizations also, known as the influence of the respective stakeholders, resulting into adoption of different strategies (Sharma \& Henriques, 2005), which have highlighted that identification of salient stakeholders is critical in formulation of strategy, emphasizing that all the stakeholders are not equally important for a strategy formulation, and their importance is relative, which changes with issues and time (Mitchell \& Wood, 1997). 
Organizational Positioning with the salient stakeholders may happen through creating positive perception of the prospective employees, the customers, the investors \& lenders and other stakeholders, who may show willingness to the products/services as more differentiated than competitors to pay premium prices, to have more loyalty etc. (Barnett, 2007; Peloza, Loock, Cerruti, \& Muyot, 2012). Organization commitment towards a specific strategy is dependent on their own perceptions (Hahn \& Scheermesser, 2006; Hou, AlTabbaa, Chen, \& Mamic, 2014), which have been prominently used by majority of previous studies as an influential determinant of stakeholder salience. The stakeholders' perceptions are the outcomes of the pieces of information that they receive (Hou, 2016), and are not only useful to extract relevant constructs to examine organizational behavior but also can disclose the stakeholders' capabilities and willingness for adoption of the strategies by the organizations (Delmas \& Toffel, 2004; Freeman, 1984; Garvare \& Johansson, 2010). Stakeholders and commercial considerations existing in separate spatial, temporal and organiational scales, result into difference in opinions and perceptions towards consequences, which is further widened by the difference in their background, objectives and interests (Frooman, 1999; Sullivan, Sullivan, \& Buffton, 2001). The divergence in their perceptions exists because of varying organizational objectives, access to information, and self-perception (Hou, 2016). Performing opinion polls globally by asking the stakeholders themselves of their views/opinions proposes a suitable reply to the concerns shown in several studies regarding construct validity of measuring the perceptions of stakeholders by asking them to express their own views/opinion (Bryman \& Bell, 2007), which further gets strengthened by the participatory approach of stakeholder analysis, used to facilitate negotiations with/ dialogue amongst the stakeholders, through the analysis of stakeholders' perceptions, knowledge, interests, relationship and experience by the stakeholders themselves, acknowledging their better understanding of their interest/values/views and tentative solutions to their problems or collective future actions (ODA, 1995).

\section{OPEN AND DISTANCE LEARNING (ODL): INDIAN LANDSCAPE}

The ODL system, with its more flexible and interactive experiences of learning, has become a significant policy choice in Higher education for most of the Governments in the Asia and the Pacific (AP) region, in the transitional education markets. The AP region, with at least seven mega universities (Institutions with more than 0.1 million active degree-level enrolments), has tremendous potential to live up to expectations of different stakeholders because of huge population of prospective learners (Jung, 2005b), and India is no exception. ODL has contributed immensely in the higher education system in India in democratizing the higher education by reaching the unreached; meeting lifelong learning demands and in increasing the Gross Enrollment Ratio (GER). The emergence of ODL system in higher education in India occured about five decades ago when policy-makers realized its imperative need to expand the higher education base, in view of the expanding base of the elementary and secondary education in the country. With the establishment of first university in ODL in 1982 as BRAOU in Hyderabad at state level, and IGNOU at the national level, other many states followed the trend which gave birth to more ODL universities in the period of 1987 onwards. While initially, the promotion and coordination responsibilities for ODL in Indian higher education was taken care of by Distance Education Council (DEC) at IGNOU instead of the UGC, an Indian Government Regulatory and Funding body for Higher Education, to reach the disadvantaged Indian learners in empowering them having access to higher education promoting quality and equality, later the Indian Government transferred the regulatory authority of DEC from IGNOU to UGC in 2013 (UGC, n.d.-b). Buttressed by the strength of about 11000 study centers and 70000 academic counselors supporting the learning needs of Indian learners, the 17 OUs with presence through out India are offering a wide array of programs including general, professional, vocational, and technical also (UGC, n.d.-a).

The key results of the All India Survey on Higher Education (2015-16) informs that there are 1 Central OUs, 13 State OUs and 1 State Private OU along with 118 Dual Mode Universities operating in India, offering education through ODL system in comparison to the total 799 Universities, 39071 colleges and 11923 Standalone Institutions, catering to the total enrolment of 34.6 million learners with 18.6 million boys and 16 million girls, with ODL system accounting for about $11.05 \%$ of the total GER of $24.5 \%$ in higher education in India. It further informs that the Central University is a university which is established/ incorporated by a Central Government Act, the State University is a university established/incorporated by a Provincial/state Act, and the Open University is a University imparting education through distance education only (MHRD, 2016). 


\section{COMPETITIVENESS IN ODL: STAKEHOLDERS' PERSPECTIVE}

Six key elements of ODL have been specified as teacher-learner separation, educational organizations influence, linkage of teacher-learner using media, two way communicational exchange, emphasis on learners as individuals instead of groups, and industrialized form of education (Keegan, 1996). ICT has proved to be an essential tool to solve a number of educational problems, although it can not be considered as a panacea for all the problems. With the advancement of ICT, ODL has become one of the most challenging professions with emergence of diverse options and new learning concepts. The growth of ODL has helped it achieve prominent goals such as taking higher educations to every corner of the developing countries, training for economic growth, offering curriculum enrichment in non conventional educational set-up, for which ICT has been used effectively in a variety of ways (Wolcott, 2003).

Like all other organizations, where five competitive forces determine their survival in the market place, the attractiveness of the ODL institutions is determined by the same five competitive forces i.e. Threat of new market entrants, Threat of substitute products, Buyers' bargaining power, Suppliers' bargaining power, and Rivalry amongst the present competitors (Porter, 1980). The most important aspect of ICT for an ODL institution in order to achieve competitive advantage is its capability to increase access and enrolments which may result into cost leadership with the help of scale economies. There has been empirical evidence that despite fixed costs being higher than conventional system, it may taste ultimately cost leadership by harnessing the positive effects of enhanced enrollments and access, reduced staff, reuse or sharing of digital contents, economy of scale, and collaborations, which may also help them gain competitive advantage through differentiation strategy with the help of products or services with better quality than their competitors, in addition to other benefits (Jung, 2005a).

The findings of a study in Zimbabwe suggests that the ODL institution ZOU, in order to gain competitiveness, took advantage of the competencies such as ability of producing study materials, deployment in different geographical areas, competency of HR, strong ICT strategy, marketing and communication effectiveness, effective student support services, effective resource mobilization, reputable programs, sound industries-institutions and learners-institutions relationships, vibrant alumni and advisory boards, and sound corporate governance (Ndudzo \& Zinyama, 2014); all of them either helping it gain cost leadership or differentiation, the important strategies for competitive advantage and highlighting the significance of the stakeholders and their perceptions. In order to fulfill the needs and expectations of its different stakeholders, ODL plays a supplementary role to the conventional system, with the help of its flexible and liberal approach without compromising the quality. The transformation in ODL in order to gain competitiveness is driven not only by the technological advancement and its adoption but by the politico-economical factors also, in view of its potential effects on different stakeholders (Carter, 2009). The general tendency of stakeholders, to show resistance, changes along with the change in their perception that their problems are being solved. It further changes positively to encourage such behaviors as they find themselves more convinced of the advantages of policies (Steg \& Gifford, 2005). In such situations, organization must make sincere efforts to know the perceptions of relevant stakeholders for identifying their needs (Freeman, 1984).

Higher education creates physical as well as social capital which, in their appropriate quantity and quality, tend to help it meet the stakeholders' satisfaction. But in recent past, its social function has been compromised due to lack of attention by the institutions towards the needs and expectations of its stakeholders (Khan, 2008). There has been lesser emphasis on other stakeholders and their relations with competitiveness of the ODL than the learners which has been central to the previous studies and researches. There appears a dire need of relevant studies to be undertaken keeping in view the access, enrolment, quality etc. of ODL by giving due emphasis to the needs and expectations of relevant stakeholders other than learners only as the future of ODL rests on principles of sustainable stakeholder management, sensing which the ZOU uses a vibrant ICT directorate to modernize communication means with its stakeholders (Chrispen, 2016). Sensitization and orientation could be effective tools to improve the perceptions and attitude of stakeholders (Chrispen, 2011) with the clarity in communication of expectations between them (Abel, 2005).

Some unique attributes of ODL include but are not limited to huge population of learners, the collective efforts of Government and institutions, increasing use of ICT and globalization of some of these institutions, which have contributed immensely to the expansion of the ODL system. Obtaining accreditations from international organizations, collaborative partnerships with national and international players, enhanced uses of ICT expansion and quality improvement, preparing to meet emerging needs, gender specific concerns, digital divide, equity and 
human rights are some of the important issues that ODL system in Indian higher education needs to address by being proactive for converting risks into opportunities and challenges into potential, instead of being merely reactive by acting according to the existing regulations, policies and standards only (Jung, 2005b). ODL can harness unique advantage of its ability to reach out to every level of society, tackling geographical challenges through education but there is a need to promote ODL among stakeholders for their awareness and creation of positive perceptions, also.

In ODL, there are many stakeholders engaged in the process of education, such as Learners, Faculty, Editors, Course Coordinators, Technical and Academic Experts, Research \& Development Staff, Librarians, Publishers, Relevant authoring tools providers, Examination observers and Invigilators, Administrative Staff, Student Services' Staff, Portal Integrators, Quality Control/Assurance Personnel, Employers, Management/ Policy Makers, Distributing and Delivery Partners, Governments, other Institutions in higher education etc., working in different units and locations along with inter and intra-departmental, and other types of interconnections, towards effective and efficient accomplishment of activities (Dambudzo, 2013). ODL system in India needs to get rid of its inadequacies to accept new models such as MOOC, OER etc. to meet the ever growing needs and expectations, which are being implemented by conventional institutions also, such as IITs (Gaba \& Li, 2015). Conventional institutes have even started to develop ODL, challenging the dominance of established ODL institutions, finds a Chinese study (LI, Yao, \& Chen, 2014). There is an immediate need for Indian ODL institutions to keep updating quality-wise their products and services in order to lead transformation and sustained development and remain competitive, also (Siaciwena \& Lubinda, 2008). There has been a visible shift in learning paradigms from 'teaching' to 'learning facilitation' and finally to 'facilitated and supported enquiry' (Brown, 2006). Which has further enhanced the chances of ODL institutions to be a viable solution in the situation where the conventional higher education institutions have been finding it difficult to make available education of good quality in their over crowded classrooms (Ural, 2007). The inherent problem with the universities is that they have tendency to internally determine their own quality and excellence and assume the needs and expectations of the stakeholders in the educational market by themselves (Lomas, 2007; Maguad, 2007), and by doing so, they tend to feel proud of themselves that they are offering the educational products and services with best quality and highest standards (Anderson, 2006). That is why, ODL system has been questioned for its quality in imparting education in the higher educational arena in spite of all its achievements and popularity, which suggests that there is divergence in the perceptions of various stakeholders of current system of ODL. ODL in higher education has, in last three decades, also witnessed globalization as another feature with a remarkable growth in the import and export of educational services. E-learning is the manifestations of a new trend, which has steadily gaining ground (Jung, 2005b). These transformations have only added another set of stakeholders in national and international arena which necessitates serious studies to identify relevant stakeholders in terms of importance and influence for the achievement of competitiveness by an ODL institution in Indian higher education.

The perceptions of the stakeholders are influenced by their beliefs about the benefits arising out of their association with ODL system/institutions as learners, teachers, employers, educational planners etc., who, benefiting from a program in satisfying their needs, will not have a positive perception only but will tend to display an enhanced performance in future also (Cavanaugh, 2005; Gagne \& Shepherd, 2001). Noncontagious communication and availability at anytime and anywhere are characteristics that make ODL attractive to adult individuals with their varied social and professional commitments (Holmberg, 1989). ODL provides to the government a means of enhancing access to learning, skilling, and cost-effectiveness of learning resources with high quality and wide variety for enhancement and consolidation of capacity; to the learners enhanced freedom of access and opportunities and a less costly alternative to conventional educational system; and to employers enhanced possibility of learning and professional development activities at the workplace in a more flexible and cost effective way. But, there are plenty of negative perceptions amongst stakeholders like educational planners and policy makers, who remain skeptical of the quality and legitimacy of the ODL system. The ODL institutions need to create positive perceptions amongst all the relevant stakeholders in order to ensure greater acceptance of ODL, who are important for and can influence the achievements of the objectives and policies of ODL institutions, as acceptance of ODL by them can determine the success of the system. Questionnaire is a popular and fundamental tool to acquire information on public knowledge and perception, which can provide precious information (Bird, 2009) to assess their perceptions. Hence, these efforts may be undertaken with the help of appropriate questionnaire. 
These key stakeholders may be Learners, Faculty, Civil Society, Parents, Decision or Policy makers, Civic Organizations, Community-Based Organizations, Formal and Non-formal Educators, Employers, Professional Associations, Career-Counselors, Faith-Based Organizations, Trade Unions, Governments, Educational NGOs, Inter-Governmental Organizations (IGOs), Donors/Funders, Other types of Educational Institutions, Educators and Support Staff (SADC, 2009). The most common negative perceptions about ODL system, generally found in the relevant stakeholders are displayed in Table 1.

The perceptions of different stakeholders of ODL are found to be different from one another and their perceptions influence the perceptions of others as well. The negative perceptions of the stakeholders are one of the major problems faced by ODL, which need to be assessed and redressed by ODL institutions in order to achieve competitiveness as positive image and reputation are known to be significant factors of competitiveness (Seyoum, 2007). There has been apparent hesitation of employers including government organizations in India, to recruit ODL learners (Gaba \& Li, 2015). In order to meet the changing needs and expectations of the stakeholders, some of the ODL institutions have taken initiatives such as updating existing curriculum, quality assurance and enhancement measures, enhanced student services, international recognition and accreditations to improve market value, collaborative partnerships, enhanced usage of ICT for quality improvement and expansion of their services (Jung, 2005b). Giving utmost attention to the stakeholders, ODL institutions in higher education need to adopt strategy in order to attain competitive advantage by attempting to equip learners with optimum level of technological and employability skills, sensing the change of winds from coordination to cooperation to finally collaborative approach, highlighting the ever increasing stakeholders' powers in meeting the strategic vision, mission, objectives and goals of the ODL institutions (Faridi \& Ouseph, 2014). The practices that may lead an ODL institution to competitiveness are related to quality assurance, focused curriculum, updated policies and effective management, Individualized and interactive student services and tutoring, ICT Innovations, Cost saving and effectiveness and for-profit involvement (Jung, 2005b), which are highly relevant and essential to meet the needs and expectations of various stakeholders.

Table 1. Undesirable Perceptions of ODL Stakeholders (SADC, 2009)

\begin{tabular}{|c|c|}
\hline Targe Group & Concerns / Misconceptions \\
\hline \multirow[t]{3}{*}{ Potential ODL Learners } & - Staying motivated while studying at a distance is difficult \\
\hline & - Will feel isolated / lonely during their studies \\
\hline & - Will struggle to balance demands of study with other aspects of life successfully \\
\hline \multirow[t]{2}{*}{ Current ODL Learners } & $\begin{array}{l}\text { - Given negative social perceptions, may be concemed that completion of their ODL } \\
\text { programme may not yield expected personal benefits }\end{array}$ \\
\hline & - May be struggling to balance demands of study with other aspects of life successfully \\
\hline Parents & - Available ODL programmes do not cater for learning needs of children \\
\hline $\begin{array}{l}\text { Employers and Professional } \\
\text { Associations }\end{array}$ & $\begin{array}{l}\text { - This froup, may be unwilling to invest money in professional development programmes } \\
\text { using ODL methods }\end{array}$ \\
\hline \multirow{2}{*}{$\begin{array}{l}\text { Educators and Support Staff } \\
\text { in ODL and Mixed Mode } \\
\text { Institutions }\end{array}$} & $\begin{array}{l}\text { - Lack of investment in design and ongoing improvement of programmes, courses and } \\
\text { materials prevents attainmentof necessary quality in ODL programmes }\end{array}$ \\
\hline & $\begin{array}{l}\text { - Engagement in ODL activities does not contribute to career advancement in traditional } \\
\text { educational systems, especially for academics }\end{array}$ \\
\hline \multirow[t]{4}{*}{$\begin{array}{l}\text { Decision-Makers in ODL and } \\
\text { Mixed-Mode Institutions }\end{array}$} & $\begin{array}{l}\text { - Average age of student enrolments is declining or will decline in face of growing } \\
\text { demand for education that cannot be met by face-to-face educations systems }\end{array}$ \\
\hline & $\begin{array}{l}\text { - Key constituency fo growing demand is young, full-time students and ODL may be } \\
\text { unsuitable for such student }\end{array}$ \\
\hline & $\begin{array}{l}\text { - Lack of investment in desing and ongoing improvement of programmes, courses and } \\
\text { materials prevents attainment of necessary quality in ODL programmes }\end{array}$ \\
\hline & $\begin{array}{l}\text { - Engagement in ODL activities does not contribute to career advancement in traditional } \\
\text { education system, especially for academics }\end{array}$ \\
\hline
\end{tabular}




\begin{tabular}{|c|c|}
\hline $\begin{array}{l}\text { Decision-Makers, Educators } \\
\text { and Career Counsellors in } \\
\text { Face-to-Face Institutions/ } \\
\text { Programmes }\end{array}$ & $\begin{array}{l}\text { - ODL demands more rigorous assurance of quality tha face-to-face programmes } \\
\text { - Key constituency of growing is young, full-time students and ODL may be unsuitable } \\
\text { for such students } \\
\text { - ODL programmes may constitute a threat either to individuals'jobs or to the institutions } \\
\text { by which they are employed } \\
\text { - Engagement in ODL activities does not contribute to career advancement in traditional } \\
\text { education systems, especially for academics }\end{array}$ \\
\hline $\begin{array}{l}\text { Government Decision- } \\
\text { Makers }\end{array}$ & $\begin{array}{l}\text { - ODL demands more rigorous assurance of quality than face-to-face programmes } \\
\text { - Key constituency of growing demand is young, full-time student and ODL may be } \\
\text { unsuitable for such students } \\
\text { - Unregulated growth of ODL will strain national education budgets }\end{array}$ \\
\hline Political Leaders & $\begin{array}{l}\text { - Key constituency of growing demand is young, full-time student and ODL may be } \\
\text { unsuitable for such students } \\
\text { - Unregulated growth of ODL will strain national education budgets }\end{array}$ \\
\hline Donors/Funders & $\begin{array}{l}\text { - Given all of above concerns and misperceptions (for all target audiences), may see ODL } \\
\text { grants as a waste of money }\end{array}$ \\
\hline
\end{tabular}

\section{CONCLUSIONS AND RESEARCH AGENDA}

This study has been attempted with the limited scope of proposing the research agenda for further research and studies related to competitiveness in ODL in higher education from stakeholders' perspective in Indian context, by providing new insights to help researchers in getting some concrete guidance for undertaking their future research. The review arranges for a starting point for future studies by providing a deeper and better understanding of the divergence in the reality and the perceptions of the stakeholders. The significance of ODL system in higher education has increased manifold, over the time, not for learners only but for other stakeholders such as governments, organizations and societies in their different roles. The review of the existing literature showcases and highlights the different aspects of the concepts of ODL, competitiveness and stakeholders and their interrelations in the context of Indian higher education. This review reveals that such kind of studies and relevant literature, which can pay desired level of attention to the stakeholders' perspective on the competitiveness of ODL in higher education have been few and far between; and there is an urgent requirement of undertaking such studies in order to create and sustain competiveness of ODL in higher education for its survival to be able to reap the rich harvest of the advantages attached to it for the benefits of the developing countries like India.

The review of literature proposes the following research agenda for future research. First, Serious efforts are required, to identify the indicators of competitiveness in ODL in Indian higher education in order to create and sustain competitive advantage for its survival in developing countries in general and India in particular, from the future researchers. Second, Majority of past studies have focused to examine and evaluate the perceptions of the learners as stakeholder of ODL in higher education in India but in the transformed scenario, greater emphasis needs to be given to the examination and evaluation of the perceptions of various relevant stakeholders to have a deeper understanding through views and opinions of important and influential stakeholders. Third, the validity of the distinction among the different key stakeholders identified, based on their importance and influence, needs to be abelempirically tested amongst primary and secondary stakeholders. 


\section{BIODATA and CONTACT ADDRESSES of AUTHOR}

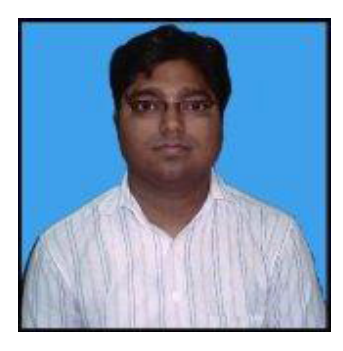

Nikhil KANT, is pursuing PhD in Management from SOMS, IGNOU, New Delhi, India and is currently working as Assistant Registrar in IGNOU. He has varied experience of 08 years in leading Public sector Banks and 08 years in Administration \& Finance in IGNOU. He has completed MBA, JAIIB, CAIIB, PGDFA, PGDDE and is UGC-NET qualified. Additionally, He is professionally trained in Soft Skills \& Applications of IT tools such as Blockchain etc. and attends training workshops as resource person on invitation. He has several publications in International Journals and participation in Conferences/Seminars..

Nikhil KANT

Address: SOMS, Research Scholar IGNOU, 110068, New Delhi, India

Phone: +91 9818469568,

E-mail: nikhilkant25apr@gmail.com

\section{REFERENCES}

Abel, R. (2005), Achieving Success in Internet-Supported Learning in Higher Education: Case Studies Illuminate Success Factors, Challenges, and Future Directions, Learning, Lake Mary, FL: The Alliance for Higher Education Competitiveness. Retrieved July 17, 2018, from http://home.fau.edu/musgrove/web/Achieving success in internet supported learning in higher education.pdf.

Agha, S., Alrubaiee, L., \& Jamhour, M. (2012). Effect of Core Competence on Competitive Advantage and Organizational Performance. International Journal of Business and Management, 7(1), 192-204.

Al-alak, B. A., \& Tarabieh, S. M. Z. A. (2011). Gaining Competitive Advantage and Organizational Performance Through Customer Orientation, Innovation Differentiation and Market Differentiation. International Journal of Economics and Management Sciences, 1(5), 80-91.

Anderson, G. (2006). Assuring quality/resisting quality assurance: Academics' responses to "quality" in some Australian universities. Quality in Higher Education, 12(2), 161-173.

Aragón-Correa, J. A., Rueda-Manzanares, A., \& Sharma, S. (2008). The influence of stakeholders on the environmental strategy of service firms: The moderating effects of complexity, uncertainty and munificence. British Journal of Management, 19(2), 185-203.

Barnett, M. L. (2007). Stakeholder influence capacity and the variability of financial returns to corporate social responsibility. Academy of Management Review, 32(3), 794-816.

Barney, J. (1991). Firm Resources and Sustained Competitive Advantage. Journal of Management, 17(1), 99-120.

Barney, J. B. (2001). Resource-based theories of competitive advantage: A ten-year retrospective on the resource-based view. Journal of Management, 27(6), 643-650.

Barrett, M., Davidson, E., Prabhu, J., \& Vargo, S. L. (2015). Service innovation in the digital age: Key contributions and future directions. MIS Quarterly, 39(1), 135-154.

Bharadwaj, A. (2000). A Resource-Based Perspective on Information Technology Capability and Firm Performance: An Empirical Investigation. Management Information Systems Quarterly, 24(1), 169-196.

Bird, D. K. (2009). The Use of Questionnaires for Acquiring Information on Public Perception of Natural Hazards and Risk Mitigation - A review of Current Knowledge and Practice. Natural Hazards and Earth System Sciences, 9(4), 1307-1325.

Brown, T. H. (2006). Beyond constructivism: Navigationism in the knowledge era. On the Horizon, 14(3), $108-120$.

Carter, D. J. (2009). Distance Education in China and India: Collectivism and Connectivism. International Review of Research in Open \& Distance Learning, 10(3), 1-7. 
Cavanaugh, C. (2005). Distance Education Success Factors. International Journal of Educational Telecommunication, 7(1), 1-6.

Chrispen, C. (2011). Revisiting quality in Open and Distance learning. Lambert Academic Publishers.

Chrispen, C. (2016). Building Stakeholders' Relatioons in Open and Distance Learning: The Quality Challenges at Play. European Journal of Business and Innovation Research, 4(2), 61-75.

Clarkson, M. E. (1995). A Stakeholder Framework for Analyzing and Evaluating Corporate Social Performance. Academy of Management Review, 20(1), 92-117.

Creswell. (2009). Research Design: Qualitative, Quantitative, and Mixed Methods Approaches (3rd ed.). Thousand Oaks, CA, US: Sage Publications Inc.

Crouch, G. I., \& Ritchie, J. R. B. (1999). Tourism, competitiveness, and societal prosperity. Journal of Business Research, 44(3), 137-152.

Dambudzo, I. I. (2013). Application of the value chain analysis framework to enhance understanding of competitive advantage at an Open and Distance Learning (ODL) Institution. Global Advanced Research Journal of Educational Research and Review, 2(3), 2315-5132.

Delmas, M., \& Toffel, M. W. (2004). Stakeholders and environmental management practices: An institutional framework. Business Strategy and the Environment, 13(4), 209-222.

Diab, S. M. (2014). Using the Competitive Dimensions to Achieve Competitive advantage (A Study on Jordanian private hospitals). International Journal of Academic Research in Business and Social Sciences, $4(9), 138-150$.

Epetimehin, F. M. (2011). Achieving Competitive Advantage in Insurance Industry: The Impact of Marketing Innovation and Creativity. Journal of Emerging Trends in Economics and Management Sciences, 2(1), 18-21.

Faridi, M. R., \& Ouseph, S. N. (2014). New Directions and Challenges for ODL: Building Collaborative Business Approach. European Scientific Journal, 1(Special), 217-223.

Freeman, E. (1984). Strategic Management: A stakeholder approach. Boston: Pitman.

Frooman, J. (1999). Stakeholder influence strategies. Academy of Management Review, 24(2), 191-205.

Gaba, A., \& Li, W. (2015). Growth and Development of Distance Education in India and China: A Study on Policy Perspectives. Open Praxis, 7(4), 311-323.

Gagne, M., \& Shepherd, M. (2001). A Comparison between a distance and a traditional graduate accounting class. T.H.E. Journal, 28(9), 4-9.

Garvare, R., \& Johansson, P. (2010). Management for sustainability - A stakeholder theory. Total Quality Management \& Business Excellence, 21(7), 737-744.

Grant, R. M. (1991). The Resource-Based Theory of Competitive Advantage: Implications for Strategy Formulation. California Management Review, 33(3), 114-135.

Hahn, T., \& Scheermesser, M. (2006). Approaches to corporate sustainability among German companies. Corporate Social Responsibility and Environmental Management, 13(3), 150-165.

Hart, S. L. (1995). A Natural-Resource-Based View of the Firm. Academy of Management Review, 20(4), 986-1014.

Heywood, C., \& Kenley, R. (2008). Evaluating the sustainable competitive advantage model for corporate real estate. Journal of Corporate Real Estate, 10(3), 160-182.

Holmberg, B. (1989). The Concept, Basic Character and Development Potentials of Distance Education. Distance Education, 10(1), 127-134.

Hou, D. (2016). Divergence in stakeholder perception of sustainable remediation. Sustainability Science, 11(2), 215-230. 
Hou, D., Al-Tabbaa, A., Chen, H., \& Mamic, I. (2014). Factor Analysis and Structural Equation Modeling of Sustainable Behaviour in Contaminated Land Remediation. Journal of Cleaner Production, 84(1), 439-449.

Jung, I. (2005a). Cost-effectiveness of online teacher training. Open Learning, 20(2), 131-146.

Jung, I. (2005b). Innovative and good practices of open and distance learning in Asia and the Pacific (APEID, UNESCO Bangkok Occasional Paper Series No. 3) (Vol. 3). Tokyo.

Kassinis, G., \& Vafeas, N. (2006). Stakeholder pressures and environmental performance. Academy of Management Journal, 49(1), 145-159.

Kaur, V. (2017). Knowledge-Based Dynamic Capabilities and Competitive Advantage: A Study of MNCs in IT Sector. (Doctoral Dissertation). The Business School, University of Jammu.

Keegan, D. (1996). Foundations of Distance Education (3rd ed.). London: Routledge.

Khan, N. Z. (2008). Higher Education and Sustainable Development: Quality vs Quantity. In 2nd International Conference on Assessing Quality in Higher Education, 1st-3rd December, 2008 (Vol. 1, pp. 69-85). Lahore, Pakistan.

Kitchenham, B. (2004). Procedures for Performing Systematic Reviews. Keele University (Vol. Keele Univ). Keele,, UK.

Krell, K., \& Matook, S. (2009). Competitive advantage from mandatory investments: An empirical study of Australian firms. Journal of Strategic Information Systems, 18(1), 31-45.

Kuettner, T., \& Schubert, P. (2012). IT-Based Competitive Advantage: A Cross-Case Comparison of Business Software Usage. Procedia Technology, 5(1), 181-189.

LI, W., Yao, W., \& Chen, N. (2014). Strategic development for advancing ODL institutions: A SWOT analysis from the Open University of China. In 28th AAOU Conference. Hong Kong.

Lomas, L. (2007). Are students customers? Perceptions of academic staff. Quality in Higher Education, 13(1), $31-44$.

Maguad, B. A. (2007). Identifying the Needs of Customers in Higher Education. Education, 127(3), 332-344.

Majeed, S. (2011). The Impact of Competitive Advantage on Organizational Performance. European Journal of Business and Management, 3(4), 191-197.

Matikiti, R., Afolabi, B., \& Smith, W. (2012). An empirical evidence on the usage of internet marketing in the hospitality sector in an emerging economy and its relationship to profitability. International Review of Social Sciences and Humanities, 4(1), 181-197.

McQuaide, S. (2009). Making Education Equitable in Rural China through Distance Learning. The International Review of Research in Open and Distributed Learning, 10(1), 1-21.

MHRD. (2016). All India Survey on Higher Education (2015-16). Department of Higher Education, MHRD, Govt. of India, New Delhi. Retrieved July 17, 2018, from http://mhrd.gov.in/sites/upload_files/mhrd/files/statistics/AISHE2015-16.pdf

Mitchell B. R. Agle, and D. J. Wood, R. K. (1997). Toward a Theory of Stakeholder Identification and Salience:Defining The Principle of Who and What Really Counts. Academy of Management Journal, 22(4), 853-886.

Ndudzo, D., \& Zinyama, T. (2014). Matching Core Competencies To Key Success Factors In Odl, Some Views From The Zimbabwe Open University. IOSR Journal of Business and Management Ver. II, 16(6), 2319-7668.

ODA. (1995). Guidance Note on How to do Stakeholder Analysis of Aid Projects and Programmes. London. Retrieved July 09, 2018, from https://beamexchange.org/uploads/filer_public/5d/4c/5d4c7b02a25d-43ab-ae33-0e4811b7c5fb/guidance_stakeholderanalysis.pdf

Peloza, J., Loock, M., Cerruti, J., \& Muyot, M. (2012). Sustainability: How Stakeholder Perceptions Differ from Corporate Reality. California Management Review, 55(1), 74-97. 
Porter, M. E. (1980). Competitive Strategy. New York: Free Press.

Porter, M. E. (1985). The Competitive Advantage: Creating and Sustaining Superior Performance. New York: Free Press.

Porter, M. E. (1990). The Competitive Advantage of Nations. (Republished with a new introduction, 1998). New York: Free Press.

Prahalad, C. K., \& Hamel, G. (1990). The core competencies of the corporation. Harvard Business Review, 68(3), 79-91.

Prescott, M. E. (2014). Big data and competitive advantage at Nielsen. Management Decision, 52(3), 573-601.

SADC. (2009). Capacity Building in Open and Distance Learning (ODL) Project: An Information, Education, and Communication Strategy for Open and Distance Learning (Final Draft). SADC Secretariat, Directorate of Human and Social Development, Gaborone, Botswana. Retrieved July 17, 2018, from https://www.sadc.int/files/7213/7820/8535/IECStrategyFinalDraftForTranslation06.05.09.pdf

Schatz, D., \& Bashroush, R. (2016). The impact of repeated data breach events on organisations' market value. Information and Computer Security, 24(1), 73-92.

Seyoum, Y. (2007). Stakeholders Perceptions and Concerns on Open and Distance Education: The Case of Eastern Ethiopia. IER Flambeau, 15(1), 17-52.

Sharma, S., \& Henriques, I. (2005). Stakeholder influences on sustainability practices in the Canadian forest products industry. Strategic Management Journal, 26(2), 159-180.

Siaciwena, R., \& Lubinda, F. (2008). The Role of Open and Distance Learning in the Implementation of the Right to Education in Zambia. International Review of Research in Open and Distance Learning, 9(1), 149-186.

Sigalas, C., Pekka Economou, V., \& B. Georgopoulos, N. (2013). Developing a measure of competitive advantage. Journal of Strategy and Management, 6(4), 320-342.

Steg, L., \& Gifford, R. (2005). Sustainable transportation and quality of life. Journal of Transport Geography, 13(Special Issue), 59-69.

Sullivan, W., Sullivan, R., \& Buffton, B. (2001). Aligning individual and organisational values to support change. Journal of Change Management, 2(3), 247-254.

Teece, D. J., Pisano, G., \& Shuen, A. (1997). Dynamic capabilities and strategic management. Strategic Management Journal, 18(7), 509-533.

UGC. (n.d.-a). Growth of ODL System in Higher Education. Retrieved July 11, 2018, from https://www. ugc.ac.in/deb/pdf/growthDEB.pdf

UGC. (n.d.-b). ODL: What, Why and How? Retrieved July 13, 2018, from https://www.ugc.ac.in/deb/pdf/ ODLwhatwhyandhow.pdf

UNESCO. (1997). Open and Distance Learning : Prospects and Policy Considerations. Retrieved July 13, 2018, from http://unesdoc.unesco.org/images/0011/001107/110752E.pdf

UNESCO. (2002). Open and Distance Learning: Trends, Policy and Strategy Considerations. Retrieved July 13, 2018, from http://unesdoc.unesco.org/images/0012/001284/128463e.pdf

Ural, O. . b. (2007). Attidues of Graduate Students toward Distance Education, Educational Technologies and Independent Learning. Turkish Online Journal of Distance Education, 8(4), 34-43.

Vahid, M. D., Mirzajani, F. S., Izadi, S., \& Asghar, A. (2013). Evaluation of the Relationship Between Competitive Advantage and Export Performance (Case study : Iranian Firms Exporting Biotech Products ). European Journal of Experimental Biology, 3(1), 364-370.

Wolcott, L. L. (2003). Dynamics of Faculty Participation in Distance Education: Motivations, Incentives, and Rewards. In M. G. Moore \& W. G. Anderson (Eds.), HANDBOOK OF DISTANCE EDUCATION (pp. 549-565). London: Mahwah, NJ: Lawrence Erlbaum Associates Inc. 